\title{
A Case Study of Miao Village in China: Cultural Identity, Change and Conservation
}

\author{
Xiaoyan Wang \\ Center for Studies of Education and Psychology of Ethnic Minorities in Southwest China, Southwest University, \\ Chongqing, China \\ Email: tq06na0@163.com
}

Received 12 January 2015; accepted 16 May 2015; published 19 May 2015

Copyright (C) 2015 by author and Scientific Research Publishing Inc.

This work is licensed under the Creative Commons Attribution International License (CC BY).

http://creativecommons.org/licenses/by/4.0/

(c) (i) Open Access

\begin{abstract}
With the accelerating process of modernization, the existing space of traditional culture is narrowed increasingly, which is the general trend of contemporary social economy and culture development. The Miao village in this thesis is unexceptionally affected by the modernization of outside world. For instance, tourism development has changed their traditional culture. However, for some reasons, the Miao village still maintains the primitive religions and burial customs such as tree worship and tree burial. Such precious traditional cultures as the Swing Festival, the village marriage custom and the characteristic costume and hair style, etc. are still seen in the village that is honored as the "living fossil" of the traditional culture of the Miao people. The survival of traditional culture always depends on the social demand; after the society opened, the survival or disappearance of traditional culture is always affected by the mainstream society.
\end{abstract}

\section{Keywords}

Miao People, Worship, Marriage Custom, Tourism, Cultural Change

\section{Introduction}

The investigation site in this thesis is a Miao village in Congjiang County of Southeast Guizhou Miao and Dong Autonomous Prefecture, where the place was with over 400 households and over 2000 people in 2009. Since people favor black in costume, they are called Black Miao, a branch of Black Miao people. Since 1999, the Miao village has been opened to the outside world as one of the first tourism villages in Guizhou province to show its unique primitive traditional culture of Miao to tourists from all over the world. It is called "the last gunman tribe in China" and reputed as the "living fossil" and the "museum" of the traditional culture of the Miao people. Although the development of tourism culture and the popularization of modern education have 
changed the traditional culture of the Miao Village a lot in the past decade, there are still some traditional cultures surviving which has become the important symbol of Miao's identity. This thesis attempts to apply social anthropology of theory to have an analysis on a part of the traditional culture, such as moral codes, marriage circle and beliefs included. The information details of the traditional cultures as followings were from my visiting to the village in 2009 .

\subsection{Old Rules}

In the village, we heard some old rules from local people which have passed down from generation to generation. Some of them are unique and interesting to us. Here I describe is the rules worked for the villagers in order to fighting against theft and sabotage, etc. purpose to protect all trees in the village and every family's properties. Gun, head of the village, told us that there was an important rule to stop stealing by buried alive in those dynasty ages, no matter how many things he stole that the thief could be buried alive. According to what Gun said that was the most serious punishment to theft, so that there was an event happened for reducing the punishment in Qing Dynasty. The reason was the villagers needed to used pine tree sticks for lighting purpose, and mostly needed to get firewood for cooking since there were fewer and fewer trees in family lands as time passed. Although there were many pine trees growing on the mountain over the village, but they couldn't fetch from it in legality, because the trees belonged to the collective of the village. According to the rules, villager who cut down the trees would be buried alive. More and more villagers had to take firewood from the collective trees in unbeknown to others for fear that violated the rules. Since the punishment seemed to be vain for the public, and the chief of the village couldn't put everyone to death that the village rules couldn't be carried out. The chief realized that it was the time to change the rules. One day, the chief came into a good idea: he made a barrel of rice white spirit and cut down pine trees on the mountain. He was caught by the villagers deliberately, and waited for his punishment. But before his punishment coming, he set up a stone monument saying the hewers would be punished for a barrel of white spirit like him, instead of being buried alive, and everyone agreed it, then they abolished the old terrible rule. From then on, no one had been buried alive by any reasons in the village. At the beginning with the new rule, the punishment was not specified in quantity or weight. The rice and white spirit for punishment were shared by the villagers averagely. Later there was specific quantity for the punishment with $60 \mathrm{~kg}$ of rice, white spirit and meat respectively. After the new rule was stipulated, there was hardly stealing in the villagers. Meeting stealing from other villages occasionally, the villagers just fired a shot to scare off them. But if someone who cut down a fir tree, he would be punished. In 2003, there was a stealing event that the thief who was from the neighbor village killed and stole the fishes in the reservoir of the village with medicinal herbs and polluted the water. After the event happened, higher organization sought for the villagers' opinions and punished the thief for $60 \mathrm{~kg}$ of rice, white spirit and meat respectively according to the village rules, did not using the state law, then the event was appeased. In addition, there were the rules for marriage protection that if a man had an affair with a married woman, he would have to compensate the woman's husband for a dog, or a sheep, or two chickens and a goose. At present, if the woman's husband doesn't pay attention to old custom, the man can compensate him for some rice white spirit and several hundred Yuan instead.

As the harshest punishment in old times, being buried alive has currently passed out of existence. However, today the parents often frighten (educate) their kids with the harsh punishment. For example, before the kids drive family's herds to the pasture mountain, parents warn the kids not to trample or steal others' crops because they themselves grow the same crops (various fruits and vegetables) in the fields. "If not, you will be buried alive”. Gun told us that it is always in good order in the village just due to the memory with the terrible rule of burying alive.

\subsection{Marriage Custom}

There are several love festivals in each year for young people of the village to choose their spouse and marriage in freedom. The first love festival is the Swing Festival in early June in Chinese lunar calendar for young men and women. As a matter of fact, young men and women, children over five or six-year-old and even married men can participate in the Swing Festival. On the festival, young person selects a big tree and hung a long rope made by his/her grandma with the straw of sticky rice. The lovers take with kippers and go to the forest, play on a swing and had a chatting there. Since girl's timid nature, she always needs help from boy while playing on the swing, so swing is a sort of way to help two lovers to be more chummy each other. 
The second love festival is on the days between January $1^{\text {st }}$ and $13^{\text {th }}$, and the third one is on the days between December $1^{\text {st }}$ and $9^{\text {th }}$ in Chinese lunar calendar, in the festivals the young men and women could have a blind date on the "Shounao" (it means "love" in Miao language) slope where a place has a enough spaces for young people. In these days, they take glutinous rice cakes and light a fire in the center of the slope. The girls will toast the glutinous rice cakes and feed to the boys. If they find in each other a congenial temper, they will fall in love (Figure 1).

Men/women choose to marry up by picking women/men with congenial temper for their spouse, the wealthy is never considered. The parents of boys' always want the girls to do well in needlework and embroidery; the parents of girls' always wish the boys to be good at farm work and able to bear hardships, etc. If not, their parents will be reluctant. But if the boy and the girl insist, the parents will respect their choice.

Although the young men/women in the village can able to choose their spouse freely, they always follow the principle of inner-village-marriage and the same-surname-marriage-forbidden. That is to say, the Guns only intermarry with the Jias and its sworn brothers of other surnames because they hold the opinion that the marriage with different surnames will give good birth. Since having a small population, the Jia family allied the latecomers as his sworn brothers, such as the Shis, the Liangs, the Mengs, the Lius, the Tangs and the Jiangs, etc. They became sworn brothers for the purpose of unity and mutual aid, and most importantly, of marriage. The Gun family has a large population. As the earliest local family, the Jias must have a matching population for intermarriage with the Guns. So the Jias made the late-comers to become sworn brothers in order to expand its population and form a matching circle for intermarriage with the Guns. Therefore, the principle is the sworn brothers are like blood brothers and cannot intermarry with each other but with the Guns. Besides the Guns, Yis can get married the Jias and its sworn brothers. The village marriage is unidirectional, that is to say, the girls are allowed to marry the boys of other villages including Han people, but the boys don't marry other girls who are from other villages including Han people.

The witch speaks blessings to the new couples on the wedding ceremony. In the past, the villagers consulted the witch for many things of life concerning, birth, death, disease, wealthy, health, harvest, long distance trip, etc. The witch was being charge of choosing tree gods for kids' healthy, holding celebrations of wedding, mediating disputes of couples, etc. To sum up, the witch is the man that the narrator of village rules and the host of religious rituals, the arbitrator of family dispute, and the host of wedding and burial ceremonies.

The witch chants the blessings for new couples in ceremonies of wedding:

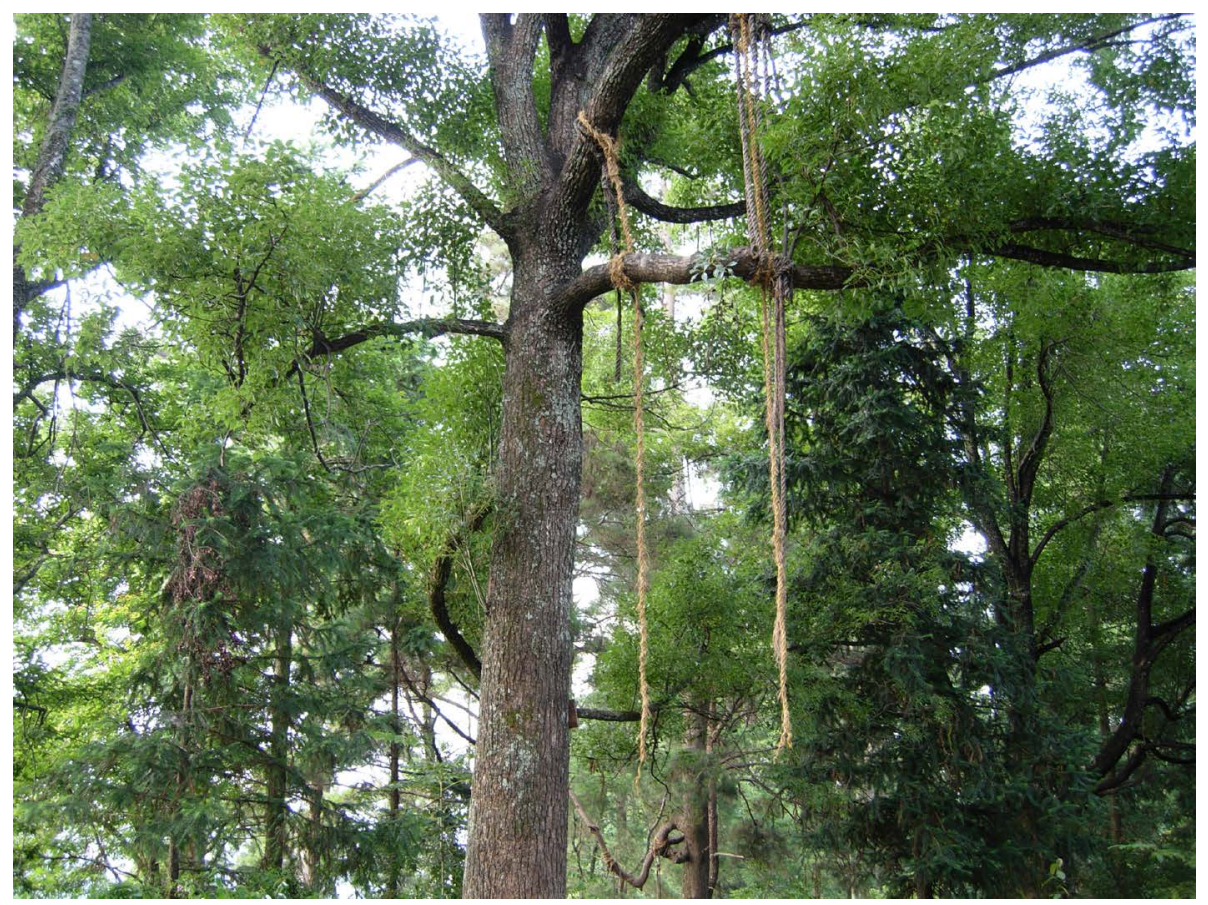

Figure 1. A used swing straw-ropes. 
Today is a tiger day ${ }^{1}$, a fine day. And the day when you get in the gate of our house on your feet while you become a member of my family we marry,

You will give birth to nine girls and ten boys,

The nine girls will wear bottom drawers some day one by one,

The ten boys will plough instead of their father one day.

They will grow strong and tall. When ten boys treading in the rice paddy fields, they might make the water turn over, and when ten boys climbing on the mountain, they might make it turn to black color ${ }^{2}$.

There are always a plenty of food and drinking for children over looking crumbs what they dropped. They can able to go on foot for three-day journey after a meal, and they can able to go on foot for three-day journey after a drinking. And they will make a fortune and make many good friends in their life.

The witch educates couples in disputing as follows:

Jar is a round, guest is at a distance, we couple can't live together in harmony and concord. We should appreciate the marriage of uneasy and we shouldn't often disagree with each other, because you are a mother and I am a father already. Since we hadn't worshiped the god while having meals and drinking so that it irritated the god, and the unhappy god made us quarrel and fight constantly, so that I have got a bad-temper to beat you. That was all my fault. Believe me, I will never do that again. Let us go to work in the field land.

The women will change their costume and even their name as long as they married. The skirt with white eight-inch-wide strip which made by handwork is what separates the married women from the unmarried that the married wears the pleated skirts with white hem and the unmarried wear that with black hem. The brides visit the husband's household for several times in the first year, then lives still in the maternal home for another two years, afterwards then permanently live in the husband's household where the women won't be called by their maternal name that she will be named the mother of the children, the daughter-in-law of the husband's father and mother and the wife of the husband. She also regards her husband's relatives as herself relatives, while she earns the appellations what corresponds to the relatives (Figure 2 and Figure 3).

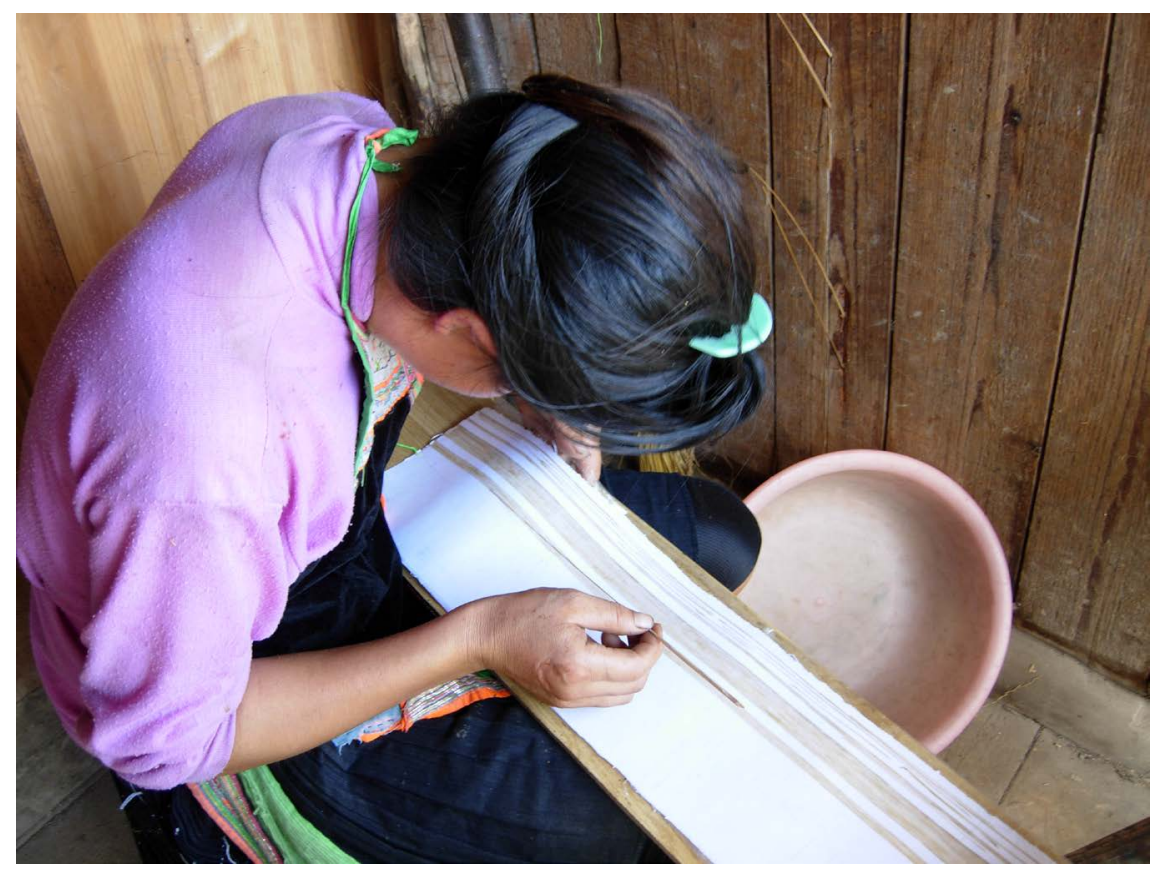

Figure 2. A woman wax painting a piece of white strip for skirt.

\footnotetext{
${ }^{1}$ This is Miao's way of calendar method for the date. Tiger is auspicious for Miao, according to its legend, they regard themselves as an ethnic group being good at hunting tigers. They use animals' name to be as a calendar method.

${ }^{2}$ Miao would like to be wearing in black color. It means many children they will have.

${ }^{3}$ The purpose of using "Jar is a round, guest is at a distance" is to be as metaphor and homophonic.
} 


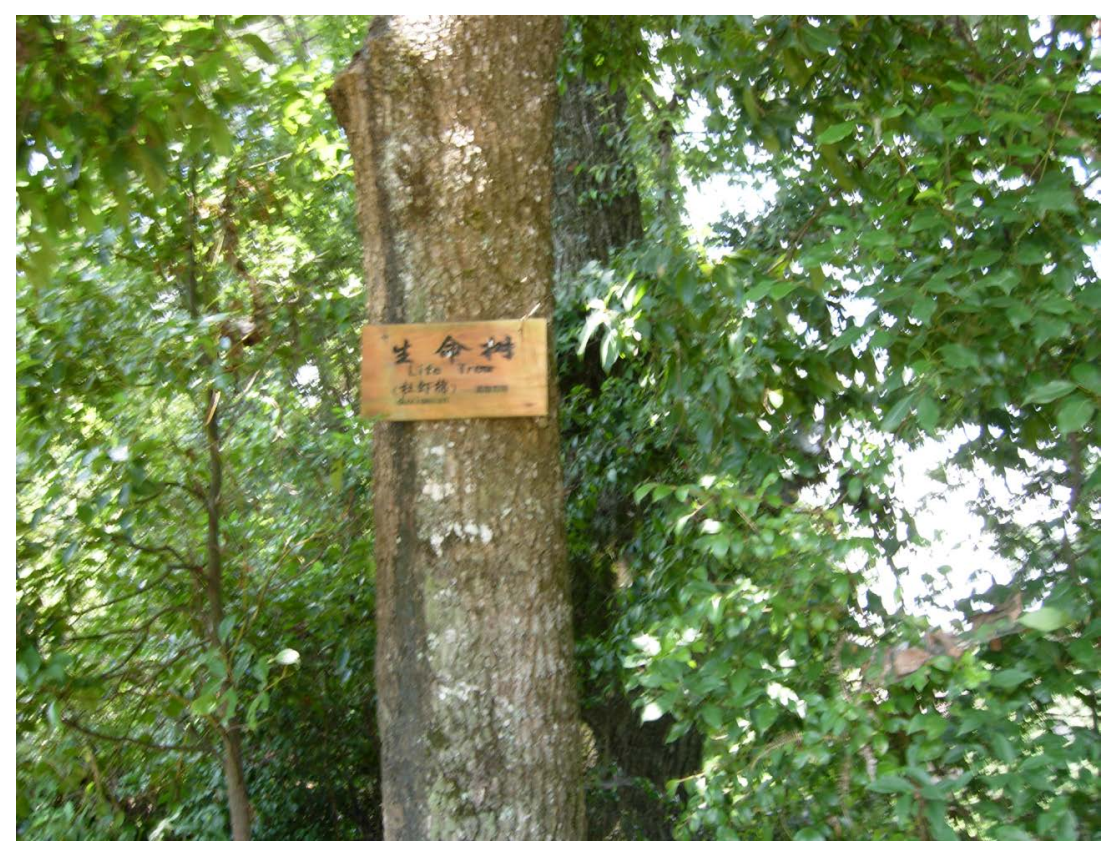

Figure 3. Hamadryad for life.

\subsection{Belief and Burial}

\subsubsection{Tree Worship}

The worship to trees is very popular in the village. The villagers regard trees, especially leafy evergreen of huge trees, as gods. They generally choose camphor tree, Chinese sweet gum as the objects of worship. If they give birth to a sickly child, the parents will come to the witch, and he will choose a leafy and indeciduate tree because it symbolizes the child will grow up as well as the tree. As for the family having the hamadryad for the child, the parents together with their child worship the tree with some liquor, meat or kippers on festivals. What food taken as sacrificial offering for the hamadryad will be up to different festivals, such as beef for Lusheng Festival, pork for Miao New Year Festival and fish for Swing Festival. So they take different sacrificial offerings. They place a flagstone in the front of the tree and put the sacrificial offerings on it. The family needs to sacrifice until the child has grown with good healthy and been strong, afterwards the tree can be chosen by another child.

Camphor tree, Chinese sweet gum and other trees are also regarded as hamadryad in the village and worshiped by villagers. They choose different trees for worship depends on their different needs. For instance, as for long-distance travel or family misfortune, they will pray for safety by worshiping camphor. There was once a camphor tree of hundreds of years in the village, which was regarded as the hamadryad by the villagers. When Chairman Mao Zedong passed away in 1976, the camphor was cut down to be sent to Beijing for the Memorial Hall of Chairman Mao. Since it was the tree of hamadryad, the villagers killed cattle to worship it before it was cut down. Later, a memorial pavilion named the "Memorial Pavilion of Camphor Tree for Chairman Mao" where the root of the tree having been consecrated was built. So far, the villagers have worshiped it by burning incenses oftentimes.

In a word, the villagers have a special affinity with tree, which is reflected in their daily life, such as the dressing imitating bark with clothe and men's hair style which is like a tree growing on the mountain. Such hair style is formed by shaving the surrounding hairs and wearing the hairs of the top in a bun, which is called "huhun" (it means "the hairs are done in a bun" in Miao language, see Figure 5). In addition, all festivals are held in the forest. People bow to worship the trees on the $1^{\text {st }}$ day and the $15^{\text {th }}$ day of each month in Chinese lunar calendar.

\subsubsection{Tree Burial}

Tree burial is a special burial custom of the Miao people. Tree burial is not to bury on the tree. But actually, if a person passes away, a fir tree which was planted by the elder generation will be cut down, and to be made a cof- 
fin. For elderly people, everyone has his own "life tree” which can be cut down to make a coffin when he dies. The trunk of the tree will be made a simple and crude coffin which the branches are sawed off to make a log. And then the dead is tied to the log and carried to the graveyard where the site had been chosen by the ancestors regarded as a good place and shared by whole village. Then put the body into the coffin made of a log and bury into the ground. There are no grave mound and no tombstone for the tomb. Afterwards, the family members would plant a tree beside the tomb or on the mountain after the burial. In addition, among many gods, sun god is one of them. When the sun rises on Feb. $2^{\text {nd }}$ and Aug. $15^{\text {th }}$ of each year, the villagers pray for family members' safety on the East Slope by worshiping the sun god with fish, meat and liquor.

\subsection{Firewood-Carrying Party}

The firewood-carrying party is a way of helping sworn brothers each other, keeping or enhancing their closer relationship. The party is held mainly by the sworn brothers of the Jias. The party I went in was that the Shis invites the Jias and other sworn brothers of the Jias to carry firewood for the Shi's family. The Shis, the Liangs, the Mengs, the Lius, the Tangs and the Jiangs all are sworn brother and sworn brother each other. The firewood was cut down by the host on the mountain before this party. The sworn brothers carried 33 loads of firewood, with everyone carrying two loads. When the sworn brothers carried the firewood to the host's house, the hostess was preparing food for them. Upon they done, the host served them a sumptuous feast for dinner. The host toasts to the sworn brothers continuously. They ate while talking, laughing and singing. In addition to drinking, the men played cards and the women had a chatting. The party went on until midnight that was attended by only brothers-in law and sisters-in-law, without children and elders. The hostess told me after the party that they didn't aim at carrying firewood, since the sworn brothers wanted to visit the Shi's family. And then she asked them to do something and have the party.

\section{Tourism Development and Conceptual Change}

The village was designated formally as a tourism village in 1999, and selected as one of the ten key construction villages under key protection of Guizhou province in 2001 and as a key scenic area of Guizhou province in 2002. Since then the village began to develop Miao cultural tourism that two troupes have been organized to perform for the tourists. The members of the village troupe include junior school students at his/her age of 13 - 17 and adult men at his age of 30s or 40s. The performances are themed by the traditional culture of the Miao people, reflecting mainly such folk life and arts as tree worship, wedding, hunting, Lusheng and hair shaving, etc. there are fifty to sixty members in a troupe usually, thirty to forty in busy season. There are about four to five hundred of performances were put on by the troupes in each year. When every show was ended up, the earning of the shows is distributed averagely to performers individual that some of them gathered in a grocery store happily to buy some snacks with small changes (Figure 4 and Figure 5).

The villagers benefited from the tourism that they have got money from the shows, and used it to buy electric fans, televisions and sewing machines. There are seven hostels managed by the villagers that serve accommodation to tourists. The hostels provide not only board and lodging and farmhouse food and special cuisine for tourists, but also salt, white spirit, snacks, beverage and basic supplies for the villagers.

It is said that the Miao people didn't touch the outside world in the past that if a Miao saw somebody Hans at the front of his door, he felt frightened and closed the door immediately. They said it was because they couldn't understand the Hans. After tourism development, they are not embarrassed again but kind to the tourists from other places. Most of men could talk fluently with Chinese language and would like to chat with the outsiders. But women, especially over forty years old who was never schooling, always feel embarrassed as their Chinese language disfluency. Since visitors are from other places, they need to receive the Chinese-speaking visitors (and a few foreign visitors), talk and do business with Chinese language and it advantages for them to speak Chinese language so that change has taken place initially in language, even the elders in their 70s or 80s who often take photos with the visitors can speak a little Chinese. In this case, tourists may not see the primitive culture of the Miao but the changed culture closer to the tourists' culture. The villagers knew that they could earn money not only from performance and tourist reception, but also from themselves and their culture. For instance, they could get a "tip" from the visitors through tour guiding, photographing, translating and witch visiting. They were scared of photographing at the beginning (because they thought photographing might take away their soul). 


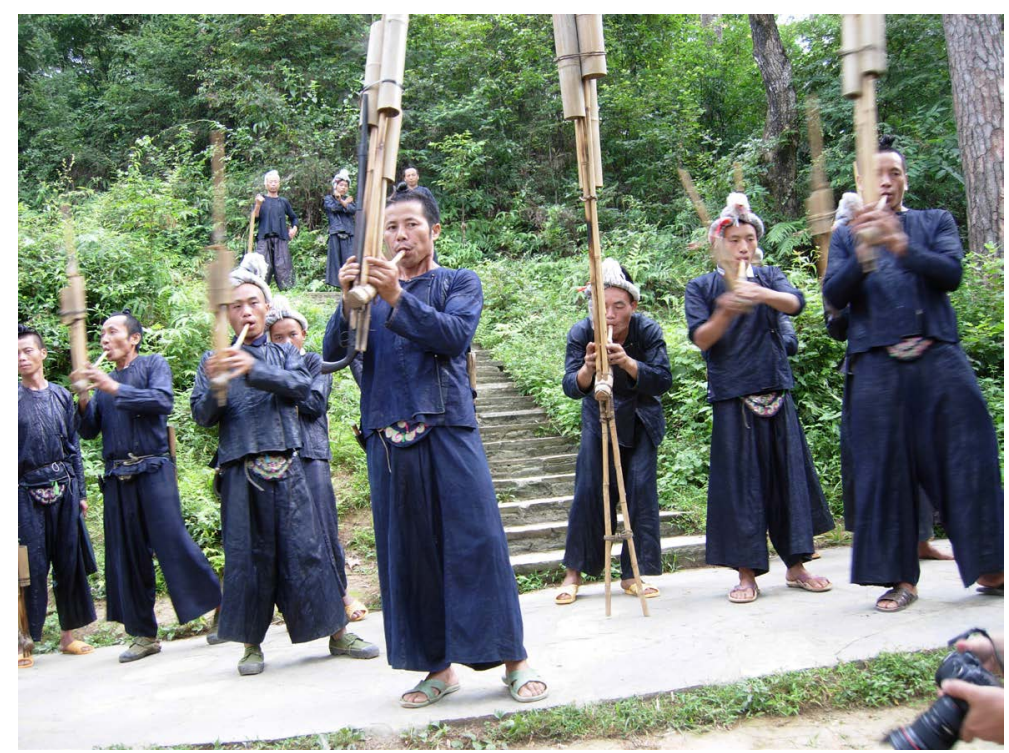

Figure 4. Music band is playing Lusheng for guests in.

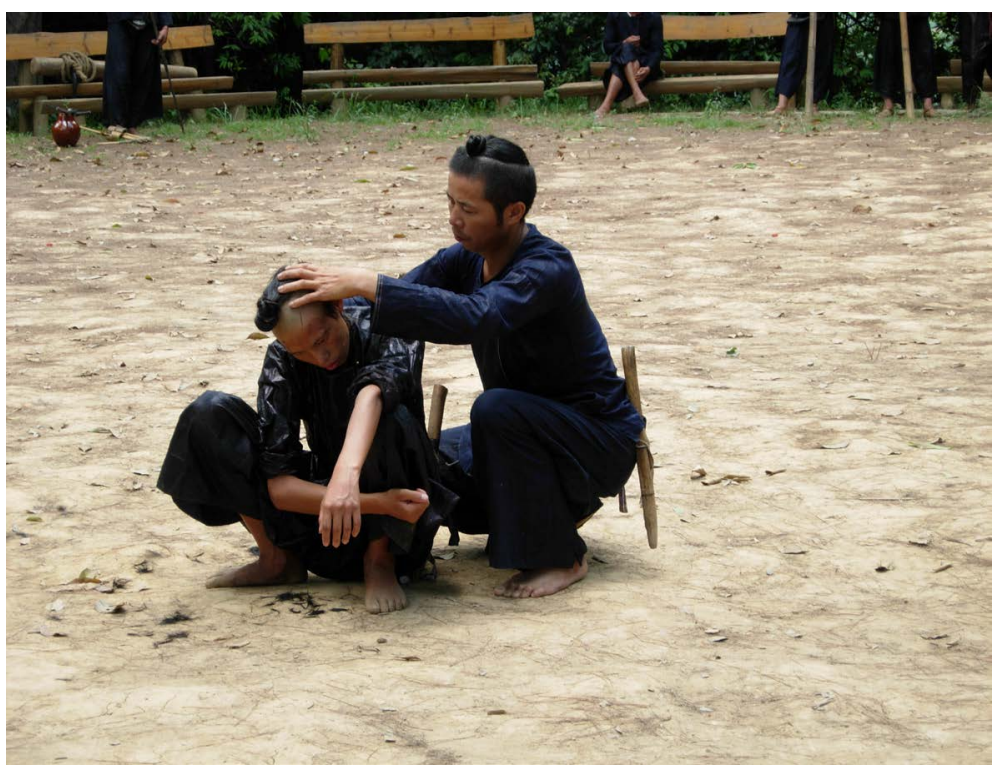

Figure 5. Cutting hair with sickle, as an item of performance.

But when they found they could earn money from taking pictures with visitors (some visitors may give them a "tip" of one or two Yuan after photographing), all village people regardless of age and sex began to enjoy it.

\section{Analyses}

\subsection{Unity Consciousness and Identity}

Since isolated from outside for quite a long time, unity and coherence among the villagers has been of key importance for collective living and development. The firewood-carrying party is right a way of helping each other among sworn-brothers and a chance of increasing communication and nurturing their relationship. When people gather together, they communicate with and affect each other. Their emotions become a common emotion and a unified moral gradually. They hold together in the heart to form a common social emotion that personal consciousness is relatively closed. However, they use a sort of secular to strengthen collective consciousness that couldn't well be enough. The relationship would be likely to get indifferent gradually as time passed that the 
common emotion would be replaced by personal emotion. Actually they knew people needed to rely on something holy objects to survive the social emotion steadily in a long term and to strengthen common consciousness constantly by worshiping. In this sense, nature (tree, sun, etc.) worship is necessary for the villagers to obtain self-awareness and create collective consciousness in the small society, and indispensable for them to maintain the consciousness. Tree worship makes all villagers evidently experience the unity and coherence (Nigel Rapport \& Joanna Overing, 2005: 309).

In anthropological concept, ideology itself can't change the social system but reflects the change of social economy and structure. The nature worship of the Miao people is not only a reflection of the traditional economy and structure but also the necessity of cultural identity for the traditional society. The worship has a close but not accidental connection with practical affairs, financial demand and critical period of life. Therefore, we can say that the worship is seemingly formed to meet certain basic needs of human (Firth, 2002: 123). The nature worship of the Miao people is a good example. They worship different trees (For example, they choose a tree for a sickly child and worship it, choose a juniper tree for family misfortune, and so son.) according to individual needs. It is a sort of utilitarian worship that the faith is often based on individual needs and benefits. "Religion in any form just meets some deep_although derived—needs of individuals and community.” (Malinowski, 1987: 77). Since living in a mountainous area, the villagers have known how important tree protection is to their life. Therefore, they have the idea of planting and protecting trees and regarding trees as life in the limited living environment, which is for the sake of survival. This reflects the true essence of cultural needs. If the culture passed down by ancestors remains their practical and indispensable base for living, the culture will survive. In a word, the village as a unit based on geographical relations and shared same culture and tradition, there always are certainly formed collective consciousness and common social emotion and identity among the villagers, so that they have reached consensus and unity as one (E·Durkheim, 1990: 245-263, 463-481).

\section{2. "Miao Oriented" and Marriage Circle}

Marriage is a direct and powerful way of the cultural exchange and integration. The Miao people of the village made a few others, the Han and the Dong people included, to be "Miao oriented" many years ago. The ex-head of the village told me there were around 30 households of the Dong who were from outside who made them into the Miao by intermarriage for seeking land and living in the village in decades ago. These Dong immigrant assimilated was right driven by a sort of intermarriage. The marriage of the village actually plays an important role to keep and promote villagers relationship. The Guns took advantage of its large population and the limitation of village inner-marriage circle specified by the ancestors to strengthen the assimilation. At least a dozen Han household who were also from outside became sworn brothers of the Jias in order to get a foothold in the village that these Han people were recognized Miao later that these Han immigrant were "Miao oriented" just like those Dong did, meanwhile the Jias needed the Hans to add number of population to compose a marriage group to match up Guns'. Then they became relatives in the intermarriage circle. The villagers could accept sworn brother relationship and relative relationship that were of significance because it tied the people in the same region speaking the same language and following the common cultural tradition and system more closely. Then a closed social structure came into being in the village.

In addition to their special marriage circle segregated the village with outside, the villagers had no need for the goods from the outside world (except salt) due to its autarky. In such a "closed” society, the systems and customs passed down by ancestors might survive, although the village is $7.5 \mathrm{~km}$ always from the county town. Actually, they didn't live in a completely closed place, the villagers used to carry firewood to the county town for sale in the past. However, compared with other Miao village, the village maintains a part of their traditional culture that was not much influenced by the outside world that we can still see the trace of their ancestors from their costume, hair style and nature worship.

\subsection{Cultural Change and Partial Conservation}

The simple and unsophisticated culture of the Miao people still survives today, which is surprising indeed. However, we have to admit the fact that since reform and opening up, especially 2000 (i.e. after the village was opened to the outside world as a tourism village), the culture of the Miao people has been changing quietly. Since the culture is formed by acquired behaviors and conceptual model, people can quit the old cultural characteristics and reacquire new cultural characteristics as the human needs vary (C·Ember - M· Ember, 1988: 564). The culture of every people is in the process of constant change and that of the Miao people is of no exception. 
Although visitors still find and enjoy Miao's traditional culture in the village, there are many changes happened. For instance, the men's shotgun is used only in performances now that was an important tool to men for hunting in the past. The needs of tourism culture has forced them to soundly preserve and inherit the external forms of cultures, including costume, hair style, song and dance and musical instrument, etc. We should know that not only the development of tourism culture but also the mainstream society promotes the change of the small society and its culture. And I take their hair style for example. Man in the troupes has to wear their hair in a "huhun" style according to their tradition. However, the boys in junior school of the county town can't wear the hair any longer because school students always discriminated against them. They are laughed at them due to wearing with the Miao unique hair style "huhun" knotted on the top of the head. So the Miao students have their hairs cut. According to the custom of the village, hair is the lifeblood of the ancestors and can't be cut. Hair cutting is a behavior of betraying the ancestors. Like tattooing, the "huhun" can be regarded as a symbol on the body and can prove that an individual has the same consciousness, thought and moral life as others in the group. Obviously, the parents don't agree their kids to cut hairs, a symbol representing the identity of the Miaos. However, they reluctantly accept their request under the new environment of mainstream culture. It explores that small group is often forced to learn culture from the dominating group when the small society has contact with a more powerful society. Facing powerful flooding of dominant culture, the villagers have no choice but to show what visitors enjoy.

It can be said that the cultural tourism has changed their value concept into a new one i.e. their original honest personality is being replaced by commodity consciousness gradually. Change has taken place in their ideology. For instance, as the economic awareness increases, tree worship has been regarded as a superstition in young people's eyes. The value of traditional concept is changing irreversibly, just as Zhang X.S. said, “They didn’t step into us (village goes into city), but usually we stepped into them in the process of modernization." What changed their destiny is our view and attitude towards them and their life. "Our concept guides their view and they are forced to change their ideas, concepts, consciousness and behaviors in every eye contact with them." (Zhang et al., 2004: 125). For the villagers, earning money from those arrival visitors means both sides, on the one hand they are happy with money bringing them better life, on the other hand they are willing to keep their old fashion and custom or finding those lost culture back as possible as they can.

\section{Conclusions}

Since isolated from outside for quite a long time, unity or coherence within the village was looked upon as an importance way for the collective living and its development. The firewood-carrying party, marriage circle and multi-god worship are the right ways of helping each other and increasing communication and nurturing emotion. In a word, based the village on geographical limited and shared the same culture, there existed certain collective consciousness and common identity among the villagers.

Although the Miao village still maintains partial of their ancestors' primitive religions and burial customs which always dependents on the social demand, traditional culture is always affected by the mainstream society. There are many changes happened in the past decades, such as men's shotgun, "Huhun" hair style, costume, even ideology. The needs of tourism culture have pushed them to pay attention to their own culture. And facing powerful flooding of dominant culture, the villagers have no choice but to show what visitors enjoy for more money. And what earning money from those arrival visitors means both sides: on the one hand they are happy with money bringing them better life; on the other hand they are willing to keep their old fashion and custom or finding those lost culture back as possible as they can.

\section{Acknowledgements}

National Funds Program of Philosophy and Social Science:[13BSH066]: A Documentary Survey of Tea-Horse Trade among Han and Tibet in Chinese history \& China State and Cultural Identity.

\section{References}

C·Ember-M·Ember, Translated by Du, S.S. (1988). Cultural Anthropology (pp. 564-565). Shenyang: Liaoning People Publishing.

E·Durkheim, Translated by Lin, Z.J., \& Peng, S.Y., Proofread by Lin, Y.H. (1990). The Elementary Forms of the Religious Life (pp. 245-263, 463-481). Beijing: Central University for Nationalities Press. 
Firth, R. Translated by Fei, X.T. (2002). Human Types (pp. 83, 123). Beijing: Hua Xia Press.

Malinowski, Translated by Fei, X.T. et al. (1987). A Scientific Theory of Culture (p. 77). Beijing: Chinese Folk Literature Press.

Nigel Rapport \& Joanna Overing, Translated by Bao, W.Y., \& Zhang, Y.H. (2005). Social and Cultural Anthropology: The Key Concepts (p. 309). Beijing, Hua Xia Press.

Zhang, X.S. et al. (2004). Miao People of the Mountains. Cultural Geography, 4, 104-125. 